\title{
MEDIEVAL BOARD GAMES: NEW FINDS FROM NOVI SAD
}

\author{
Aleksandar Sajdl \\ Petrovaradin \\ e-mail: aleksandar.sajdl@gmail.com | Original scientific paper \\ Received: 23. 4. 2021. UDC: 904:794"653"(497.113) \\ Accepted: 9. 6. 2021.
}

\begin{abstract}
Rescue excavations of Old Petrovaradin unearthed two Larger Merels gaming boards crafted between the second half of the $13^{\text {th }}$ and the $15^{\text {th }}$ century from old, secondhand, repurposed bricks. After providing a sketch of the site's research history, the paper describes the boards and examines the archaeological context they came from. Chronologically closest and territorially nearest analogies for these boards come from Vrbas and Bač. A brief overview of historical and archaeological contexts associated with Larger Merels boards and gaming paraphernalia across Europe offers clues for possible interpretations of similar finds from the south of the Carpathian Basin. They testify that in the late Middle Ages game(s) on Larger Merels boards were played in various social contexts in settlements of different sizes and importance.
\end{abstract}

Keywords: Novi Sad, Old Petrovaradin, board games, Merels, Nine men's morris, Middle Ages

"If you like to gamble, I tell you I'm your man

You win some, lose some, it's all the same to me The pleasure is to play, makes no difference what you say"

(Motörhead 1980, Ace of Spades)

\section{Prologue}

The city of Novi Sad (Serbia) lies on the left bank of the river Danube. Through the city's northern outskirts runs the international route E-75. Construction of the so-called Temerin cloverleaf interchange, an integral part of the traffic bypass around Novi Sad on route E-75, started in 2007. In advance of the construction works, a team of archaeologists from the Provincial Institute for the Protection of Cultural Monuments had excavated the area. Two fragmented bricks with incised linear patterns, most probably gaming boards, were found. This is their story. 


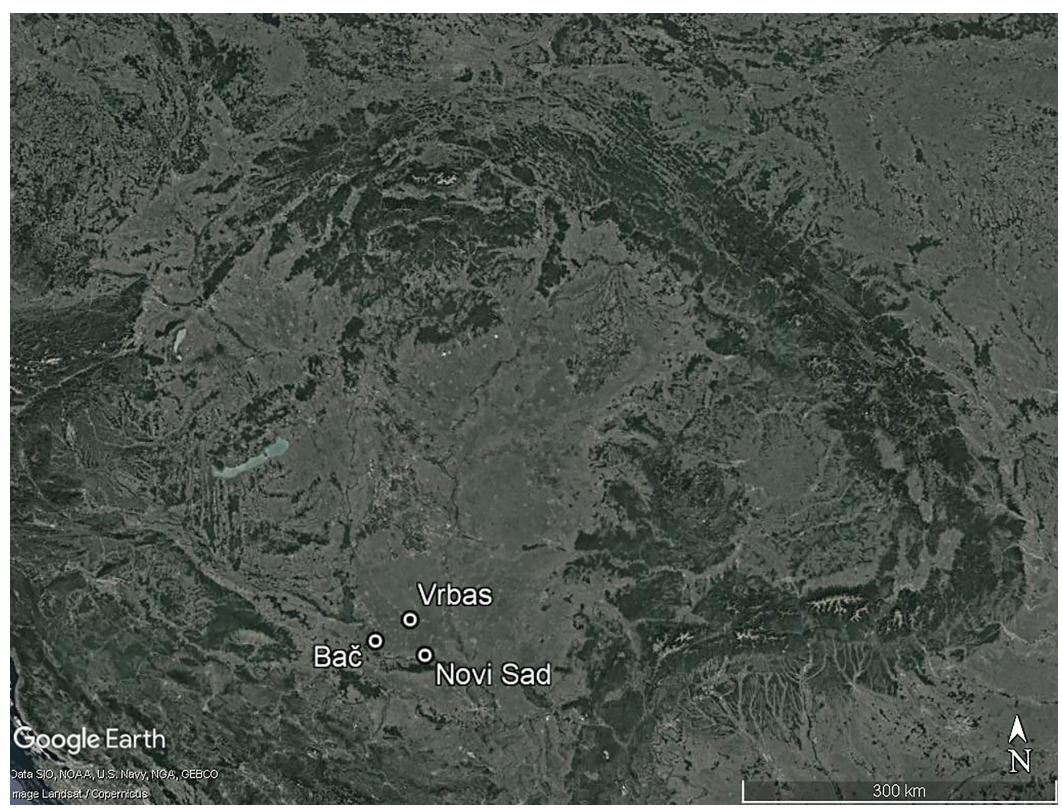

Fig. 1. Map of the Carpathian Basin (source: Google Earth)

Сл. 1. Карта Карпатског басена (извор: Google Earth)

\section{Where it all began}

On the Danube's left bank, Novi Sad is situated at the very south of the Carpathian Basin (Fig. 1). Over time, the landscape of this area changed considerably. The Danube river bend was much larger in the past, reaching farther north, with wide floodplains and marshes surrounding it. What is the northern periphery of Novi Sad today used to be the Danube marshland bank in the past. The old bank is still visible in the landscape (Pl. I, II).

At the end of the $19^{\text {th }}$ century, following the descriptions from medieval written sources and studying the topography of the area, historian M. Érdujhelyi decided to excavate "on both sides of the Temerin road near the gunpowder magazine" because that was the highest ground on the old bank and was not flooded in the past (Ердујхељи 1990, 48). He was convinced this was the location of Old Petrovaradin, a settlement referred to as Varadino Petri, Peturwarad, VasárosVárad, or Ó-Péterváradjá in sources written between the $13^{\text {th }}$ and the $16^{\text {th }}$ century (Csánki 1894, 141; Ердујхељи 1990, 44-48). Érdujhelyi's efforts bore fruit. He discovered pieces of medieval bricks, large stones, traces of mortar mixed with charcoal, human skeletons, and a fragment of a column of "a pure Romanesque style" - all indicating the existence of a church at the site (Ердујхељи 1990, 48-50, 77-78). 
Toponym Klisa, a contemporary urban neighbourhood where the archaeological site is located, also suggests the existence of a medieval church. The toponym derives from Greek É $\chi \chi \lambda \eta \sigma i \alpha$ (Грујић 1935, 227; Skok 1972, 101). According to R. Grujić, it marks a location of old church ruins or remains. He related the appearance of the toponym in the southern Pannonia and in the western Balkans with Turkish conquests in the $15^{\text {th }}$ and the $16^{\text {th }}$ century (Грујић 1935,227$)$.

Almost a century after the pioneering endeavours of M. Érdujhelyi, archaeologists conducted rescue excavations in the area of the so-called Temerin traffic bypass (Pl. II) - the Museum of Vojvodina in 1981 and the Provincial Institute for the Protection of Cultural Monuments in 1982 ("Gunpowder magazine" site). The excavations revealed a horizontally stratified, multi-layered site formed on the southern edge of the Danube's loess terrace, at the elevation of $80-83 \mathrm{~m}$ above sea level. A section of the site with remains of prehistoric and medieval settlements was excavated. The medieval one was dated into the period between the $12^{\text {th }}$ and the $15^{\text {th }}$ century (Stanojević 1982, 128-130; Станчић 1987, 26; Станојев 1996, 114).

Archaeologists from the Provincial Institute for the Protection of Cultural Monuments excavated the site again in 2007. Besides the remains of prehistoric and medieval settlements, several medieval graves were discovered as well, reinforcing the hypothesis of the existence of a church in the Middle Ages.

\section{T(h)rash till game}

The 2007 campaign brought to light two features, each in a separate section of the site, each containing a brick fragment with an incised linear pattern. Feature 19 was a rectangular pit $(260 \times 140 \times 50 \mathrm{~cm})^{1}$ with rounded corners and sides sloping gently towards the uneven bottom. The southern side of the feature cut through an older and smaller pit with prehistoric pottery and stone tools. Feature 32 was a barrel-shaped pit (184 x $140 \times 240 \mathrm{~cm}$ ) with an oval base and opening.

Both features yielded small sherds of cooking pots thrown on a fast potter's wheel. The pots were made of clay with the addition of sand and fired in shades of a reddish or brownish colour. One of the pieces was decorated with shallowly incised horizontal lines (P1. III/7). The rims of the pots are short and leaning outward. They are usually strongly profiled, sometimes with a groove on the lip (Pl. III/3-8; Pl. IV/2-4) but simple and rounded rims occur as well (Pl. III/9). Small in numbers and size, the potsherds do not allow further conclusions about the shape and decoration of the pots. The pottery produced in similar technique and fashion was found on several sites in the southern Carpathian Basin

\footnotetext{
${ }^{1}$ Dimensions for features are given in the length-width-depth format.
} 
and dated into the period between the second half of the $13^{\text {th }}$ and the $15^{\text {th }}$ century (Станојев 1996, 63, fig. 4/22, 68, fig. 4/35, 112, fig. 11/3, 155; Анђелић 1999, 113, 117-119, T. IV-VI; Зечевић 1997, 188, 196, T. V/2-5). A rim of a glass bottle was also recovered from Feature 19 (Pl. II/2). With the utmost caution it could be attributed to a biconical bottle ${ }^{2}$, a vessel type common in the Carpathian Basin, produced between the $13^{\text {th }}$ and the $15^{\text {th }}$ century (Хан 1978, 173-174, сл. 1; Gyürky 1991, 25-27, 88-89, Abb. 2-3; Mester 2010, 652, Fig. 10).

Regularly shaped and shallow rectangular Feature 19 might have been some sort of a structure partially dug into the ground, probably too small to be a dwelling. Deep, barrel-shaped Feature 32 was presumably used for storage. Both were subsequently filled in with garbage. One thing is certain: both contexts are domestic.

Each collection of medieval garbage contained one brick fragment, each bearing a symmetric, linear pattern on one of its broad sides. Lines are irregular. They were incised with a sharp object after the bricks were fired and there are no traces of mortar in the incisions. The brick $(140 \times 120 \times 65 \mathrm{~mm})$ from Feature 19 (Pl. III/1) has barely a quarter of the pattern preserved. Similar in size $(138 \times 114 \times 72 \mathrm{~mm})$, the brick from Feature 32 (Pl. IV/1) contains almost half of the pattern.

The pattern consists of three concentric rectangles. The midpoints of corresponding sides of each rectangle are connected by a single straight line. As a rule of thumb, researchers associate this distinguishable and easily recognisable design with the game popularly known as Nine men's morris (e.g. Hall 2015; Константинов 2007; Petényi 1994; Полякова и Фехнер 1973). Corners of the rectangles and intersections of the lines constitute points, i.e. places on the pattern where gaming pieces can be positioned, while the network of lines determines their movement (Murray 1952, 5-6, 38, fig. 18/F). Depending on the context, however, this distinctive pattern could have possessed meanings other than that of a gaming board (Berger 2004, 11-13; Parker 1909, 578).

Simple irregular bricks from Klisa with crudely incised irregular linear patterns found in settlement garbage pits were most probably used as gaming boards. Presumably, bricks were initially utilised for the construction of a medieval church

\footnotetext{
${ }^{2}$ The archaeological documentation describes the fragment as "yellowish" only, without any further details. The photograph (P1. II/2) seems to show that the surface colour of the glass is rather brown. This could indicate that the bottle was made of low-quality, brittle, potassium glass that, over time, gets covered by a brownish surface layer. If so, the fragment could be dated into the middle or the second half of the $15^{\text {th }}$ century (Хан 1978, 173; Mester 2010, 652; Бикић 2011, 293). Unfortunately, this remains a conjecture only for the time being because the author was unable to access the fragment and examine it in detail.
} 
that once dominated the site. Archaeological context and the lack of mortar in the incisions suggest they were extracted from the church after it was destroyed, converted to portable gaming boards, and finally disposed of after they were broken.

\section{Gaming boards and other paraphernalia}

A gaming board, the key element of board games, can be any surface with a specific pattern on which a game is played (Murray 1952, 1; Parlett 1999, 5). In our case: common bricks with the pattern commonly associated with Nine men's morris, a game that belongs to a group of board games collectively called Merels, where players aim to align and connect three gaming pieces in a row. The group name derives from low Latin merellus, pl. merelli meaning a "token", "counter", or "gaming piece" (Murray 1952, 38; Parlett 1999, 109). In the Middle Ages, a line of three counters in a row was known as a "mill" 3 in Germanic languages (Murray 1952, 37; Parlett 1999, 116). Accordingly, Nine men's morris is alternatively known as Larger Merels, and the pattern is sometimes referred to as a "triple mill" (Murray 1952, 43; Parlett 1999, 118-119). We should be aware of potential regional and chronological differences in the way a specific gaming board is used. Bearing in mind that different games and game types could be played using the same board design (Parlett 1999, 121; Rogersdotter 2015, 491, n. 5), further in the paper the author refers to the pattern commonly associated with Nine men's morris as "Larger Merels pattern" and any surface where the pattern occurs as "Larger Merels board". Although not simple or elegant, these phrases are less burdened with meaning, allowing for the possibility that the boards were used for any type of game with counters, not necessarily Nine men's morris or a "mill" type of game.

In medieval Europe, players would have used either stationary or portable Larger Merels boards. Stationary ones were created by incising the characteristic pattern into various architectural features, frequently occurring on ecclesiastical and monastic sites (Bakay 1981, 179, 49. kép; Feld et al. 1979, 34, 37, 34. kép; Murray 1952, 44; Овчаров 1994, 51, 71, обр. 131-132; Rabinowitz et al. 2010, 449, fig. 24; Robertson 1967, 321-322, fig. 6; Томов 2013, 437, 449-452, фиг. I/1-4; Wolf $2014,629,633$, fig. $1 / 3$ ). These so-called graffiti boards are extremely difficult to date because the time when a structure was built can be used as a terminus post quem only (Crist et al. 2016). Portable boards were made of wood (Hansen 1998, 72, 73, fig. 11b; Nicolaysen 1882, 46, Pl. VIII/1b; Полякова и Фехнер 1973, 441,

\footnotetext{
${ }^{3}$ A multitude of European languages adopted the term as the name for "three-in-a-row" games (Murray 1952, 39; Parlett 1999, 116): deu. Mühle, hun. malom, fra. moulin, rus. ме́льница, srp. млин, slk. mlyn.
} 
puc. 2/3), stone (Hall 2015, 283-287; Richterová 1983, 210, obr. 10, 211), bricks (Feld et al. 1979, 36; Petényi 1994, 69; Станојев 1996, 78; Станојев 2019, 234, бр. 62) or tiles (Станојев 2019, 231, бр. 29; Vroom 1999, 94-96, 98, Pl. III, 99, fig. 3).

The origin of the Larger Merels boards remains a mystery. There is no firm evidence of their existence in prehistoric Ireland or Pre-Roman Egypt and Greece (Berger 2004, 15; Crist et al 2016; Vroom 1999, 102-104), although earlier scholars suggested so (cf. Murray 1952, 18-19, fig. 7F, 26, 44; Parker 1909, 578, 644, fig. 273/12). The earliest examples come from northern Bulgaria - a slate from a burial dated into the early $3^{\text {rd }}$ century BC (Nankov 2013, 279, 287, fig. 12), and southern France - a tile dated into the period between $100 \mathrm{BC}$ and AD 40 (Berger 2004, 15). Subsequently, they appear in various contexts from the Late Iron Age to Late Antiquity (Berger 2004, 15; Hanel 1997, 318; Јанковић 2008, 11, no. 15, fig. 13; Vroom 1999, 105).

The lack of both written and physical evidence could indicate that games were not played on Larger Merels boards in most of Europe for quite some time after the fall of the Western Roman Empire. Sporadic board finds from early Byzantine Israel (Sebbane 2000, 226-228, fig. 1-2; Vroom 1999, 107) and early medieval Bulgaria (Константинов 2007, 85-86) suggest some games persevered in the east. Caution is advised, though, as "absence of evidence is not evidence of absence" (Sagan 1997, 210). Players in the west could have preferred drawing the pattern in dirt or making boards out of perishable materials.

Larger Merels boards reappear on European archaeological sites from the Viking age onwards. Famous high-status boat grave from Gokstad (Norway) from the $10^{\text {th }}$ century contained a wooden board with lavishly decorated points (Nicolaysen $1882,46, \mathrm{Pl}$. VIII/1b). Wooden boards were recovered from a $9^{\text {th }} / 10^{\text {th }}-$ century settlement in Toftanes (Faroe Islands) (Hansen 1998, 72, 73, Fig. 11b) and the $10^{\text {th }}$-century layer in Staraya Ladoga (Ста́рая Лáдога) (Russia) (Полякова и Фехнер 1973, 441, pис. 2/3), both with strong Viking connections (e.g. Richards $2005,58,60,97-98)$. Between the $9^{\text {th }}$ and the $11^{\text {th }}$ century, the pattern appears at the far east of Europe in Tmutarakan (Тмутарака́нь) on Taman peninsula (Russia) scratched on tiles, clay and stone tablets (Рыбаков 1957, 89-90, рис. 6-10). According to T. Tоmov (Томов), there is a possibility that Vikings in service of the Byzantine Emperor could have engraved Larger Merels patterns in Hagia Sophia (Istanbul, Turkey), playing some version of the game between the end of the $10^{\text {th }}$ and end of the $11^{\text {th }}$ century (Томов $2013,447-448$ ).

The earliest medieval Larger Merels boards from the Carpathian Basin date back to the $11^{\text {th }}$ century: cornice engraving from Somogyvár basilica (Bakay 1981, 179, fig. 49) and a brick from the Kardoskút church walls (Feld et al. 1979, 
36; Petényi $1994,69, \mathrm{n} .176)$. Late in the $11^{\text {th }}$ or early in the $12^{\text {th }}$ century, two patterns were scratched into a hard plastered floor of a dwelling discovered in Gorzsa (Wolf 2014, 629, 633, fig. 1/3). Almost two centuries earlier (in AD 895/896), Hungarian tribes conquered the Carpathian Basin, forming the Principality of Hungary. In AD 1000, the Principality became a great kingdom that dominated the area until the end of the Middle Ages (Рокаи et al. 2002, 13-218). According to some scholars, the early presence of Larger Merels boards in small settlements and domestic contexts suggests that Hungarian tribes could have become familiar with Nine men's morris before arriving in the Basin - possibly through contacts with Byzantine, Arab, or Viking world - and brought it with them (Petényi 1994, 69, 74, n. 179; Wolf 2014, 629). The boards appear on several medieval ecclesiastical sites in Hungary (Wolf 2014, 629). Besides being used as a pastime by masons and builders, some authors hypothesise that the pattern associated with religious architecture could have possessed a symbolic meaning as well (Gömöri 1972, 172-173; Wolf 2014, 629). Bricks, roof tiles, and architectural features with Larger Merels patterns were also found in Visegrád, Buda (one on a window sill), Fonyód, Solymár, Csövár, and Eger castles, mostly dated into the $15^{\text {th }}$ and the $16^{\text {th }}$ century (Feld et al. 1979, 34, 36, 37, 34. kép; Kozák 1966, 103; Petényi 1994, 69).

Territorially nearest analogies for the boards from Novi Sad come from Vrbas and Bač. A brick board $(240$ x 134 x $68 \mathrm{~mm})$ from a medieval settlement in Vrbas (Pl. V/3) was dated into the $15^{\text {th }}$ century. The pattern was scratched on one of its broad sides after the brick was fired (Вукотић и Станојев 1998, 28, бр. 90; Станојев 1996, 78). Presumably, the brick was used in the construction of a $13^{\text {th }}$-century church that was discovered at the site. After the church was ruined, some bricks were reused in dwellings (Вукотић и Станојев 1998, 19; Станојев 1996, 77). Other details were not published.

A board made from a reused Roman brick ( $200 \times 276 \times 56 \mathrm{~mm})$ was found in Bač (Pl. V/1) in the vicinity of a Franciscan monastery church built in the first half of the $13^{\text {th }}$ century (Станојев 2019, 19, бр. 4). Roman bricks were substantially reused after Ottoman conquests of this area in the $16^{\text {th }}$ century (Станојев $2019,23)$. Therefore, this board cannot be dated indisputably. Two additional boards were discovered in Bač castle, built in the $15^{\text {th }}$ and the beginning of the $16^{\text {th }}$ century (Станојев 2019,163). One of the trapholes between the entrance gate and the barbican yielded a roof tile gaming board $(\mathrm{Pl} . \mathrm{V} / 2)(155 \times 155 \times 20 \mathrm{~mm})$ and a sword (Станојев 2019, 164, 169, бр. 34, 231, бр. 29). Based on the shape of the pommel, crossguard, and blade, the sword could be dated into the $15^{\text {th }}$ century (Aleksić 2007,105$)$. Finally, a brick gaming board ${ }^{4}(330$ x 180 x $65-70 \mathrm{~mm})$ came

\footnotetext{
${ }^{4}$ A drawing or a photograph of the board showing the Larger Merels pattern were not published.
} 
from a cultural layer formed between the palace and the keep, as can be deduced from the location description and the site plan (Станојев 2019, 234, бр. 62, 257).

Archaeology has not yet delivered a complete gaming set for games played on Larger Merels boards. As a rule of thumb, boards are found alone. Apart from a board, a set could have contained gaming pieces or counters at least, as the name of the game itself suggests (Murray 1952, 38; Parlett 1999, 109). Libros de acedrex dados e tablas, a $13^{\text {th }}$-century games compilation from Spain, explains that Nine men's morris is played with "nine pieces of one color and nine of another [...] round and long like chess pawns" (Musser 2007, 625-626). Other medieval sources portray elaborate red and gold pieces shaped like a star, moon, shield, cross, square, and disc in association with Larger Merels boards (Fiske 1905, 105-106; Parlett 1999, 119).

In reality, gaming pieces could have been small objects of any kind that could have been obtained in sufficient numbers, fit on the pattern, and recognised by players as such. Players could have used simple pebbles, pottery fragments, shells, or perishables like seeds or beans (Murray 1952, 7). They could have equally played with custom-made pieces. Archaeologists excavating the south region of Byzantine Chersonesos have associated bone counters found "throughout [their] excavation area" with Nine men's morris. Combinations of dots and lines depict either a cross or a six-pointed asterisk on these counters (Rabinowitz et al. 2010, 449, n. 80). Several monastic sites in Scotland yielded counters that could have been used for a similar game (Hall 2015, 284-286, Table 1). Three beautiful counters carved from serpentinite and dated into the beginning of the $13^{\text {th }}$ century were recovered from the most recent medieval layer in the fortress of Gradina at Pazarište; perhaps Nine men's morris or a similar game was played there as well (Popović 1999, 270, sl. 235/1-3, 364, cat. no. 550-552). Gaming pieces could have also been made of perishable materials. A permanent exhibition in the Museum of Yugoslavia displays chess pieces made from bread by prisoners in Sremska Mitrovica penitentiary. Although recent, these objects testify to the resourcefulness and creativity of the human mind. The nature of the gaming pieces could explain why they evade archaeological records. Simple pebbles, shells, or beans (if they survive) most probably would not be recognised as gaming paraphernalia if not directly associated with a gaming board. If a gaming board would have been broken and thrown away, gaming pieces could have been saved and reused or repurposed, especially if an effort was invested to craft them. Earth would digest the organic ones.

According to Libros de acedrex dados e tablas, Nine men's morris could have been played with or without three cubic dice (Musser 2007, 604-607, 625-626). 
To the best of the author's knowledge, dice or other implements of chance haven't been found in the Carpathian Basin in association with Larger Merels boards.

\section{The game}

Although several medieval written sources from western Europe mention and illustrate game(s) played on Larger Merels boards, reconstructing the gameplay is not a straightforward task. Libros de acedrex dados e tablas, a compilation of games played in $13^{\text {th }}$-century Spain, commissioned by King Alfonso $\mathrm{X}$ of Castille and León and finished in 1283, describes two versions of a game in detail: one played with and the other without cubic dice (Musser 2007, 625-626). Scholarly debate over the exact use of dice does not seem to be concluded (Murray 1952, 45-46; Musser 2007, 604-607, 625-626; Parlett 1999, 121; Schädler 2000). Two manuscripts originating from northern Italy - Bonus Socius, from the $13^{\text {th }}$ century, and Civis Bononiae, written before 1450 - contain collections of game(s) problems, but lack the rules (Fiske 1905, 104-106; Hooper and Whyld 1992, 53, 80-81; Murray 1952, 2-3, 45). Some sources illustrate Larger Merels board (Murray 1952, 44; Parlett 1999, 118; Robertson 1967, 321; Vroom 1999, 100, Fig. 4), but illustrations alone do not provide enough information about the game(s) played.

Even if we could fully reconstruct the gameplay from the available sources, we could not be certain that identical game(s) were played or uniform rules followed in the Carpathian Basin. Written and pictorial sources describing and depicting game(s) played on Larger Merels boards are completely missing in this area and archaeological evidence is scarce at best. Game rules vary in space and time (e.g. Berger 2004, 14; Murray 1952, 43-48). Historical and social contexts differ significantly: we cannot simply presume that Spanish kings and courtiers played in the same way as villagers and townsfolk from southern Hungary. Game rules are not set in stone. They are subject to change, adjustment, and negotiation even at an individual level. Players can simply agree on how they want to play.

\section{Who, when, and where}

Although the anonymous author of the poem De Vetula, written in France in the $13^{\text {th }}$ century, was ashamed to mention minor games such as Merels (Murray 1952, 3; Schädler 2000, 112), it was a game worthy of royalty. Along with chess and other board games, it was detailed in a collection of games commissioned by the King of Castille and León (Musser 2007). Clergymen and monks did not abstain from it, as evidenced by numerous boards from churches and monasteries in Scotland and England (Hall 2012; Hall 2015, 293; Murray 1952, 44). Even 
Templars were allowed to play "marelles" (Upton-Ward 1992, 90). Ladies played it as well, as one $14^{\text {th }}$-century Flemish miniature portrays (Vroom 1999, 100, Fig. 4). Reference to Merels in the introduction of Civis Bononiae shows its popularity among the common folk (Murray 1952, 45). Model French shepherds could enjoy it in times of leisure (Endrei and Zolnay 1986, 67). It was the game of the peasantry and urban poor according to late medieval satires (Hall 2011, 157).

Written sources on medieval Hungary do not mention Merels or similar games specifically. Various sources such as legal and religious texts or poetry mention games and play in general. Gambling was regulated by law and condemned by the Church while the attitude towards games and play in general was not uniform (Petényi 1994, 10-35). In that respect, Hungary was not alone. The same mindset reigned over western Europe (Endrei and Zolnay 1986, 13-17; Dean 2014; Hall 2015, 291-294). Similarly, in Slavic lands surrounding Hungary, as well as in the Byzantine Empire, canons of the Eastern Orthodox Church strictly forbade gambling to both laymen and clergy, and even watching others gamble was prohibited (Бојанин 1999, 317; Томов 2013, 446-447; Бојанин 2019, 510-512). Most games can be the means for gambling, which can lead to crime (theft, brawl, murder), but also to blasphemy, making them subject to legal and religious authorities (Dean 2014). In medieval Serbia, gamblers played board games like chess, draughts or backgammon (Бојанин 1999, 317). Merels could be used for gambling as well, as illustrated in the Rule of the Templars: "a brother of the Temple should play no other game except marelles, which each may play if he wishes, for pleasure without placing wagers" (Upton-Ward 1992, 90). Legal prohibitions and recommendations were repeated and gambling regulated to minimise negative effects, but gaming could not be prevented (Petényi 1994, 34-35). Moral condemnation by the Church or even destructive measures of the $15^{\text {th }}$-century preachers who would burn gaming equipment on great public bonfires had no permanent effect either (Endrei and Zolnay 1986, 11).

Archaeology shows game(s) on Larger Merels boards could have been played in public (stationary boards) or privacy of one's home, in villages, monasteries, or castles alike. By its nature, these game(s) demand no elaborate expensive boards or specially crafted gaming pieces. Rules can be fairly simple and do not require players to be educated. Games need no purpose other than to relax and provide means for pleasure and escape from reality (Hall 2011, 146; Petényi 1994, 35). Apart from space and gaming paraphernalia, they ask for free time only. But the time was not an issue. In medieval Hungary, even common folk had up to 100 or 150 non-working days in a single year (Endrei and Zolnay 1986, 11; Petényi 1994, 50-51). 
Gaming boards from Old Petrovaradin, Vrbas, and Bač demonstrate that board games reached the very south of the Hungarian kingdom. Old Petrovaradin was a prominent medieval settlement that belonged to a Cistercian abbey founded on the opposite side of the Danube that served as the central place for the collection of taxes on goods. Its medieval name (Vasáros-Várad) suggests it was a fortified trading centre where fairs were organized (Ердујхељи 1990, 41-50). Fairs were places where games were commonly played ${ }^{5}$, and players would wander from fair to fair (Endrei and Zolnay 1986, 10; Petényi 1994, 14). It was perhaps through fairs that game(s) have found their way to Old Petrovaradin. Maybe even Cistercian monks have introduced them to the area, as playing games (including Merels) was a common practice among European monks and clergymen. Crudely sketched on plain bricks quarried from church ruins and discarded in settlement garbage pits, boards from Old Petrovaradin were most likely used by town inhabitants trying to entertain themselves. Given the context of the finds and materials used, we can conjecture that the players were of a lower social status and that the boards were not designed for a special occasion. However, other interpretations should not be discarded easily; e.g. if illegal gambling was involved, people from different social strata could have succumbed to it. A similar board found between the keep and the palace in the Bač fortress warns against such rush interpretations as well because anyone with access to the castle could have used it. The Roman brick board found near the church of the Franciscan monastery in Bač cannot be accurately dated. If the pattern was scratched on the brick in the Middle Ages, its find-spot could shed light on the players. Maybe they were friars, playing between themselves or interacting with the neighbouring common folk. Roof tile gaming board from a traphole of the Bač fortress found with a sword could reflect the monotony of guard duty. Information is scarce for the medieval Vrbas and the gaming board found there but its existence demonstrates game(s) on Larger Merels boards were played in smaller, late medieval settlements as well.

\section{Acknowledgments}

I owe a great debt of gratitude to recently deceased Dragan Anđelić. As an archaeologist from the Provincial Institute for the Protection of Cultural Monuments, he was in charge of the excavations of Klisa, Novi Sad, in 2007. When I was a student and later a very young professional, Dragan provided me with an opportunity to work with his team and learn from them. Not so long ago, he allowed me to publish gaming boards from Klisa. Ivana Pašić from the same institution was kind to locate and share the documentation from the excavations with me.

\footnotetext{
${ }^{5}$ An interesting example comes from medieval Serbia, Hungary's southern neighbour, where temporary marketplaces were organised as part of religious festivities (panēgyreis), accompanied by various economic and social activities. Makeshift taverns were raised where people ate and drank, but also gambled, possibly by playing board games (Бојанин 1999, 317; Бојанин 2005, 137-149).
} 


\section{REFERENCES}

Aleksić, M. 2007. Mediaeval Swords from Southeastern Europe. Material from 12th to 15th Century. Belgrade: M. Aleksić.

Анђелић, Д. 1999. Касносредњевековно насеље на потезу Биштанске Салашине у атару Бачке Паланке. Грађа за проучавање споменика културе Војводине XX: 112-119. Bakay, K. 1981. A magyar államalapitás. Budapest: Gondolat Könyvkiadó.

Berger, F. 2004. From circle and square to the image of the world: a possible interpretation for some petroglyphs of merels boards. Rock Art Research 21/1: 11-25.

Бикић, В. 2011. Посуђе из некропола касног средњег века на подручју централног Балкана. Старинар LXI: 285-306.

Бојанин, С. 1999. Коцка(ње), у Лексикон српског средњег века, ур. С. Ћирковић и Р. Михаљчић, 317. Београд: Knowledge.

Бојанин, С. 2005. Забаве и светковине у средњовековној Србији: од краја ХII до краја $X V$ века. Београд: Историјски институт и Службени гласник.

Бојанин, С. 2019. Заповести светих отаца из Требника библиотеке манастира Зограф (рукопис бр. 50), у Наслеђе и стварање. Свети Ћирило. Свети Сава: 8691219-2019, том II, Старословенско и српско наслеђе књ. 2, ур. Ј. Радић и В. Савић, 499-523. Београд: Институт за српски језик САНУ.

Crist, W., Dunn-Vaturi, A. and de Voogt, A. 2016. Ancient Egyptians at play: board games across borders. New York: Bloomsbury Academic, an imprint of Bloomsbury Publishing Plc.

Csánki, D. 1894. Magyarország történelmi földrajza a Hunyadiak korában. 2. köt. Budapest: Magyar Tudományos Akadémia.

Dean, T. 2014. Crime in medieval Europe 1200-1550. Abingdon, Oxon; New York: Routledge. Endrei, W. and Zolnay, L. 1986. Fun and games in Old Europe. Budapest: Corvina.

Ердујхељи, М. 1990. Историја Новог Сада. Нови Сад: Добра вест.

Feld, I., Jakus, L. and Csaba, L. 1979. Csövár. Studia Comitatensia 7: 7-62.

Fiske, W. 1905. Chess in Iceland and in Icelandic Literature. Florence: The Florentine Topographical Society.

Gömöri, J. 1972. A sárospataki r. k. plébániatemplom kőfaragó és kőelhelyező jelei. Magyar Müemlékvédelem VI: 161-174.

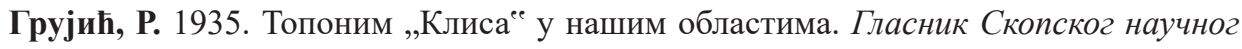
друштва XIV: 227-229.

Gyürky, K. 1991. Üvegek a középkori magyarországon. Budapest: Budapesti Történeti Múzeum.

Hall, M. 2011. Playtime everyday: the material culture of medieval gaming, in A history of everyday life in medieval Scotland, 1000 to 1600, eds. E. J. Cowan and L. Henderson, 145-168. Edinburgh: Edinburgh University Press.

Hall, M. 2012. Des jeux gravés dans la pierre: graffiti des cathédrales, monastères et églises paroissiales en Grande-Bretagne. Histoire et Image Médiévales Thématiquen 28: 30-33.

Hall, M. 2015. Ecclesia Ludens: board and dice games in a Scottish monastic context. Proceedings of the Society of Antiquaries of Scotland 145: 283-297. 
Хан, В. 1978. Значај налаза стакла на београдској тврђави. Годишњак града Београда XXV: 169-176.

Hanel, N. 1997. Sonderkeramik in der Militärziegelei? Zu einer tabula lusoria mit Mühlespiel und Legionsstempel. Kölner Jahrbuch 30: 317-320.

Hansen, S. S. 1998. The Norse Landnam in the Faroe Islands in the light of recent excavations at Toftanes, Leirvik. Northern Studies 25: 58-84.

Hooper, D. and Whyld, K. 1992. The Oxford companion to chess. Oxford, New York: Oxford University Press.

Јанковић, М. 2008. Римске игре на табли у Сингидунуму и околини. Годишњак града Београда LV: 1-14.

Константинов, К. 2007. За игрите на населението в Плиска, в Епископ-Константинови четения. Т. 10. Ч. ІІ, ур. Д. Димитров, 82-91. Шумен: Унверситетско издателство “Епископ Константин Преславски”.

Kozák, K. 1966. Az egri vár feltárása (1957-65) III. Annales Musei Agriensis 4: 97-152. Mester, E. 2010. Üvegművesség a középkorban és a kora újkorban, in $A$ középkor és a kora újkor régészete Magyarországon, szerk. B. Elek és Gy. Kovács, 643-673. Budapest: Magyar Tudományos Akadémia Régészeti Intézete.

Murray, H. 1952. A history of board-games other than chess. Oxford: Clarendon.

Musser, S. 2007. Los libros de acedrex dados e tablas: Historical, Artistic and Metaphysical Dimensions of Alfonso X's Book of Games. Dissertation. University of Arizona http://hdl.handle.net/10150/194159.

Nankov, E. 2013. Playful in life and after death: board games in early Hellenistic Thrace, in The Thracians and their neighbors in the Bronze and Iron Ages. Vol. 2: Necropolises, cult places, religion, mythology. Eds. V. Sîrbu and R. Ştefănescu. Proceedings of the 12 th International Congress of Thracology. September, 10-14 2013, Târgovişte, Romania, 277-288. Braşov: Editura Istros a Muzeului Brăilei.

Nicolaysen, N. 1882. Langskibet fra Gokstad ved Sandefjord. Kristiania: A. Cammermeyer. Овчаров, Н. 1994. Проучвания върху средновековието и по-новата история на Вардарска Македония: ново след Йордан Иванов. София: Университетско издателство „Св. Климент Охридски”.

Parker, H. 1909. Ancient Ceylon. London: Luzac.

Parlett, D. 1999. The Oxford history of board games. Oxford: Oxford University Press.

Petényi, S. 1994. Games and toys in medieval and early modern Hungary. Krems: Medium aevum quotidianum.

Полякова, Г. Ф. и Фехнер, М. В. 1973. Игра в мельницу в древней Руси. Slovenská archeológia XXI/2: 441-444.

Popović, M. 1999. Tvrđava Ras. Beograd: Arheološki institut.

Rabinowitz, A., Sedikova, L. and Henneberg, R. 2010. Daily life in a provincial late Byzantine city: recent multidisciplinary research in the south region of Tauric Chersonesos (Cherson), in Byzanz - das Römerreich im Mittelalter, eds. F. Daim and J. Drauschke, 425-475. Mainz: Verlag des Römisch-Germanischen Zentralmuseums. 
Рыбаков, Б. 1957. Архитектурная математика древнерусских зодчих. Советская археология 1: 83-112.

Richards, J. 2005. The Vikings: a very short introduction. Oxford, New York: Oxford University Press.

Richterová, J. 1983. Pražské středověké hrací kostky a kameny. Archaeologica Pragensia 4: 201-223.

Robertson, W. N. 1967. The game of merelles in Scotland. Proceedings of the Society of Antiquaries of Scotland 98: 321-323.

Rogersdotter, E. 2015. What's left of games are boards alone: on form, incidence, and variability of engraved game boards at Vijayanagara. Heritage: Journal of Multidisciplinary Studies in Archaeology 3: 457-496.

Рокаи, П., Ђере, 3., Пал, Т. и Касаш, А. 2002. Историја Мађара. Београд: Clio.

Sagan, C. 1997. The demon-haunted world: science as a candle in the dark. London: Headline.

Schädler, U. 2000. Medieval nine-men's morris with dice. Board games studies 3: 112-116.

Sebbane, M. 2000. Two game boards, in Ramat Hanadiv excavations: final report of the 1984-1998 seasons, ed. Y. Hirschfeld, 226-231. Jerusalem: The Israel Exploration Society. Skok, P. 1972. Etimologijski rječnik hrvatskoga ili srpskoga jezika. Knj. 2, K-poni. Zagreb: Jugoslavenska akademija znanosti i umjetnosti.

Станчић, В. 1987. Прилог познавању археолошке топографије Новог Сада, Петроварадина и Сремске Каменице. Грађа за проучавање споменика културе Војводине XIV: 25-30.

Станојев, Н. 1996. Средюовековна насеља у Војводини. Нови Сад: Музеј Војводине. Станојев, Н. 2019. Бач: археологија. Нови Сад: Музеј Војводине; Петроварадин: Покрајински завод за заштиту споменика културе.

Stanojević, N. 1982. Stari Petrovaradin, Novi Sad - srednjovekovno naselje. Arheološki pregled 23: 128-130.

Томов, Т. 2013. Игра на “дама” в храма “Св. София”, Константинопол, в Българско средновековие: обштество, власт, история. Сборник в чест на проф. д-р Милияна Каймакамова, съст. Г. Н. Николов и А. Н. Николов, 437-452. София: Университетско издателство “Св. Климент Охридски”.

Upton-Ward, J. M. 1992. The Rule of the Templars: the French text of the rule of the order of the Knights Templar. Woodbridge: Boydell Press.

Vroom, J. 1999. Playing games in the valley of the Muses: a medieval board game found in Boeotia, Greece. Pharos VII: 93-110.

Вукотић, Д. и Станојев, Н. 1998. Музејска збирка Врбас: водич. Врбас: Дом културе. Wolf, M. 2014. Gorzsai homo ludens. Malomjáték egy Árpád-kori házban, in Avarok pusztái: régészeti tanulmányok Lorinczy Gábor 60. születésnapjára, szerk. A. Anders, Cs. Balogh és A. Turk, 627-636. Budapest: Martin Opitz Kiadó.

Зечевић, Е. 1997. Преглед керамичког материјала са локалитета Град у Ковину. Рад Музеја Војводине 39: 185-197. 


\title{
Александар Сајдл
}

Петроварадин

\section{СРЕДЊОВЕКОВНЕ ИГРЕ НА ТАБЛИ: НОВИ НАЛАЗИ ИЗ НОВОГ САДА}

\author{
Кључне речи: Нови Сад, Стари Петроварадин, \\ игре на табли, игра мице, средњи век
}

Приликом заштитних ископавања извршених 2007. године на северној периферији Новог Сада (простор тзв. Темеринске петље), археолози Покрајинског завода за заштиту споменика културе истражили су, између осталог, део позносредњовековног насеља подигнутог на старој обали Дунава, из средњовековних извора познатог као Варадино Петри, Петурварад, Вашарош Варад и Стари Петроварадин. У испуни плитко укопане грађевине правоугаоне основе (Објекат 19) и оставе бачвастог облика (Објекат 32) пронађен је по један уломак опеке са урезаном мустром која се по правилу доводи у везу са игром „мице”. На основу уломака грнчарије и стакла, објекти су оквирно датовани у раздобље између друге половине 13. и 15. столећа.

Територијално и хронолошки најближе аналогије за табле из Новог Сада потичу из Врбаса и Бача. Кратак осврт на европску историју и археологију прибора за игру који се доводи у везу са игром „мице”, са нагласком на простор средњовековне Угарске, послужио је као основа за сагледавање налаза из Војводине и испредање претпоставки о њиховој појави и употреби на југу Карпатског басена. У Стари Петроварадин игра(е) на табли за „мицу” могле су стићи путем вашара, а могли су их са собом донети и Цистерцити. Налази са војвођанских налазишта сведоче да су се игре на табли за „мицу” у позном средњем веку играле у мањим насељима попут Врбаса, важним трговачким центрима попут Старог Петроварадина и утврђењима попут Бача. На основу контекста налаза и начина израде, претпостављено је да су табле из Старог Петроварадина користили становници града из нижих друштвених слојева у жељи да разбију монотонију свакодневице, али ни друге могућности нису искључене. Таблу пронађену надомак фрањевачког самостана у Бачу могли су користити монаси, играјући се међусобно или са околним становништвом. Мустра на црепу који је откривен са мачем из 15. столећа у испуни вучје јаме утврђења у Бачу можда би могла бити одраз доколице на стражи. 

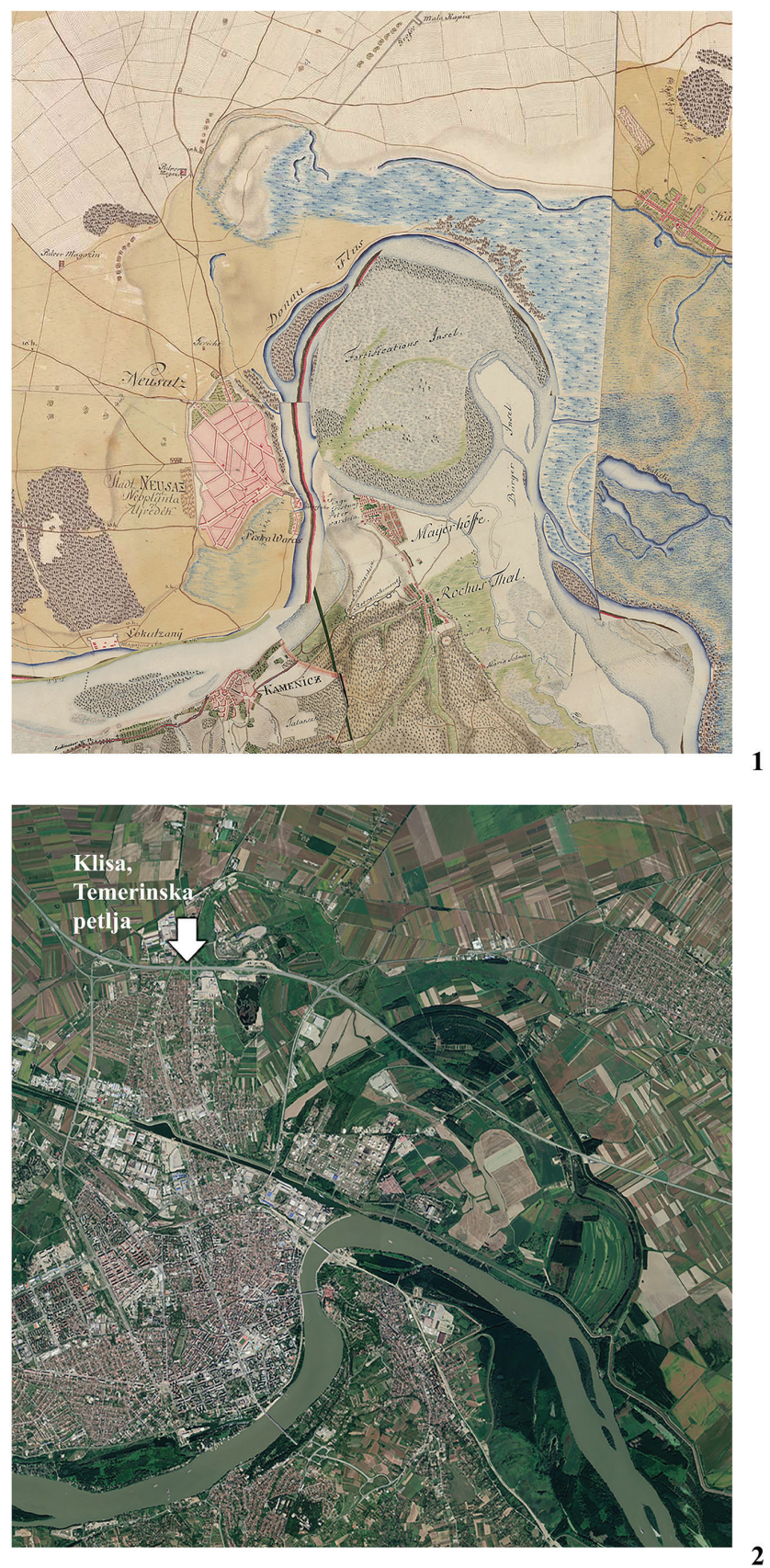

PI. I 1. Novi Sad, map (source: Königreich Ungarn - First Military Survey (17631787), accessible at https://mapire.eu/en/map/europe-18century-firstsurvey/);

2. Novi Sad, map (source: Google Earth)

T. I 1. Нови Сад, карта (извор: Königreich Ungarn - First Military Survey (17631787), доступно на https://mapire.eu/en/map/europe-18century-firstsurvey/);

2. Нови Сад, карта (извор: Google Earth) 

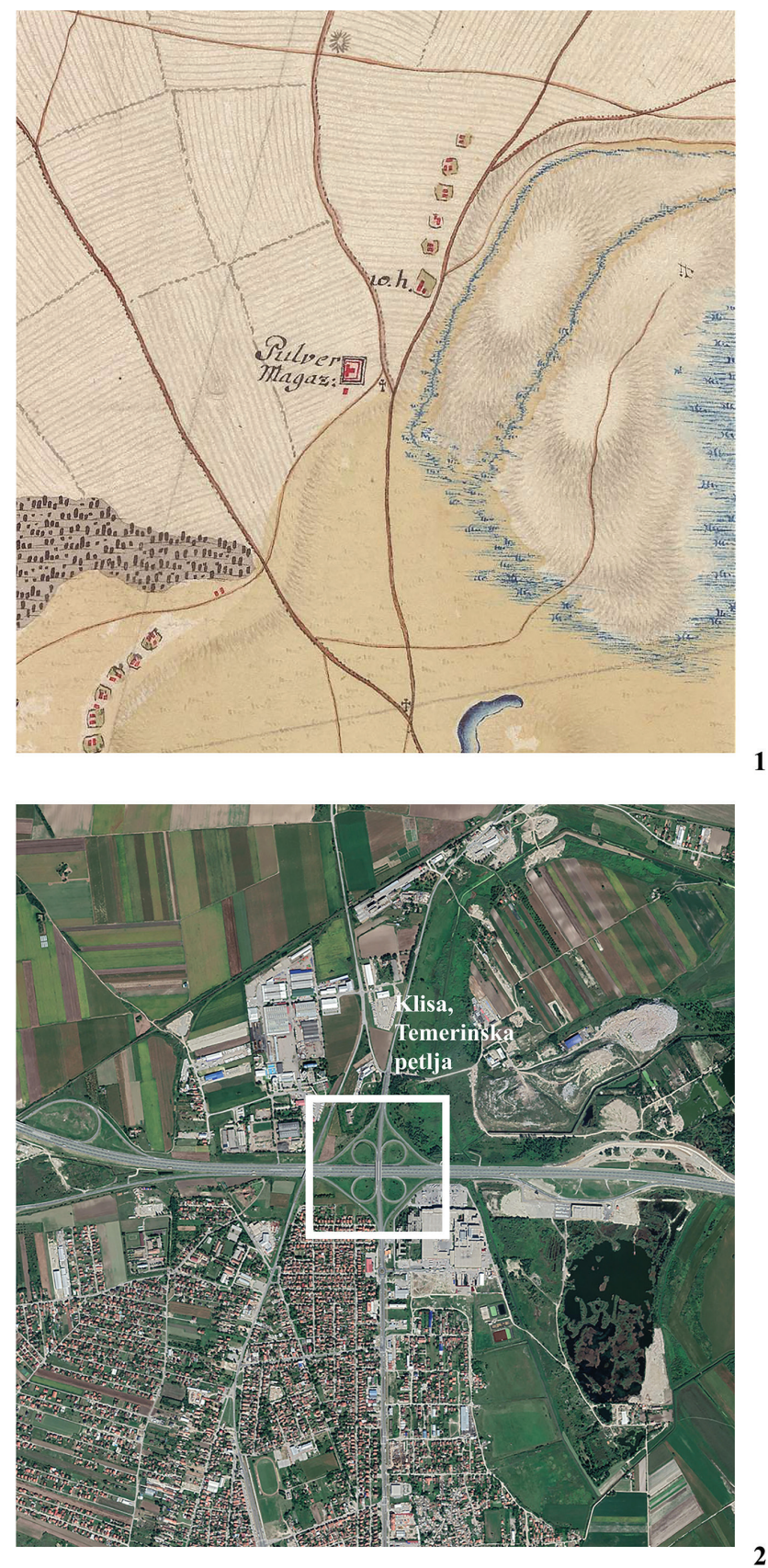

PI. II 1. Novi Sad, Gunpowder magazine, map (source: Königreich Ungarn - First Military Survey (1763-1787), accessible at https://mapire.eu/en/map/europe-18centuryfirstsurvey/); 2. Novi Sad, Temerin cloverleaf interchange, map (source: Google Earth)

T. II 1. Нови Сад, Стара барутана, карта (извор: Königreich Ungarn - First Military Survey (1763-1787), доступно на https:/mapire.eu/en/map/europe-18centuryfirstsurvey/); 2. Нови Сад, Темеринска петља, карта (извор: Google Earth) 

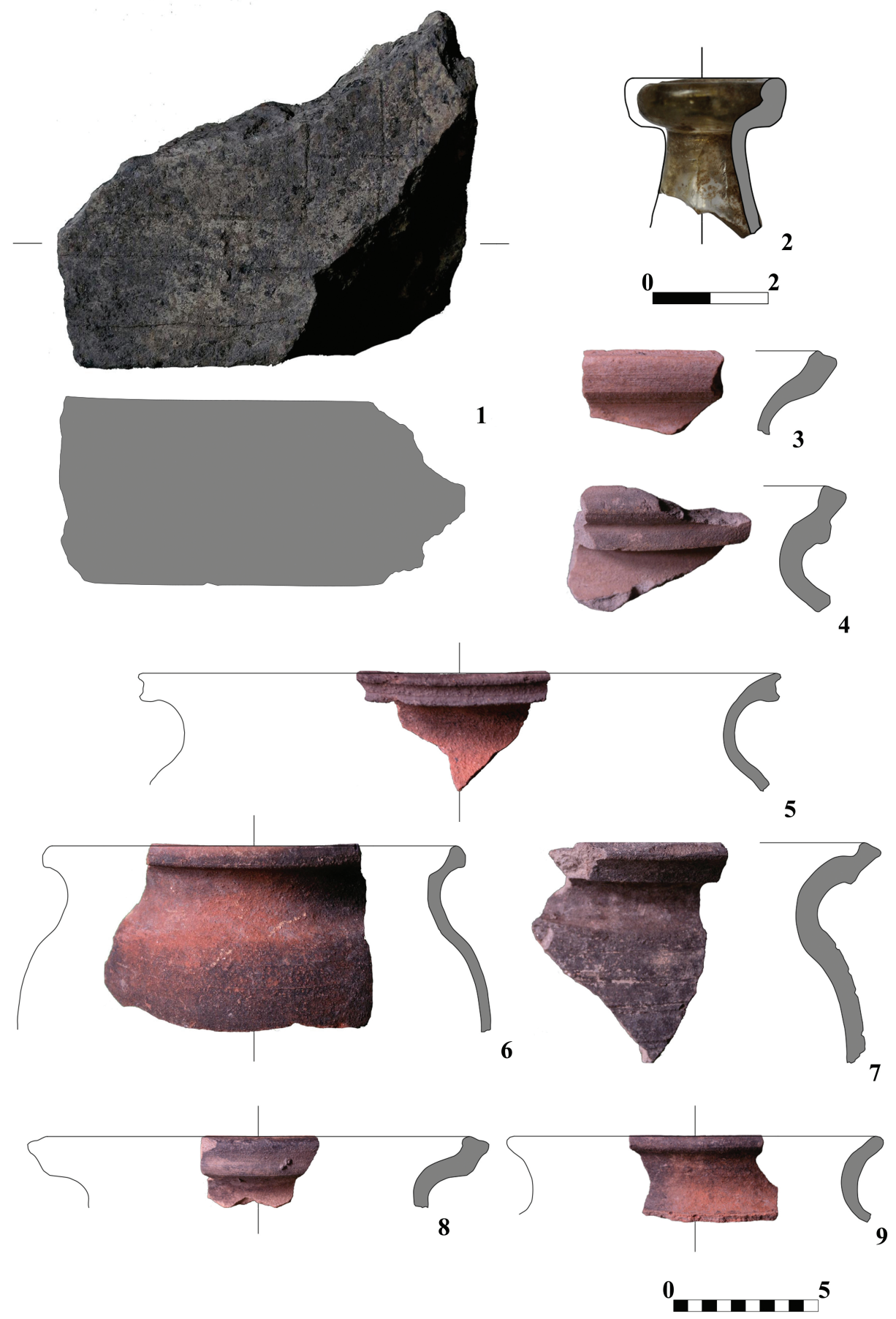

Pl. III Novi Sad, Klisa, finds from Feature 19 (drawing: V. Mogin; photo: D. Anđelić) T. III Нови Сад, Клиса, налази из Објекта 19 (цртеж: В. Могин; фото: Д. Анђелић) 

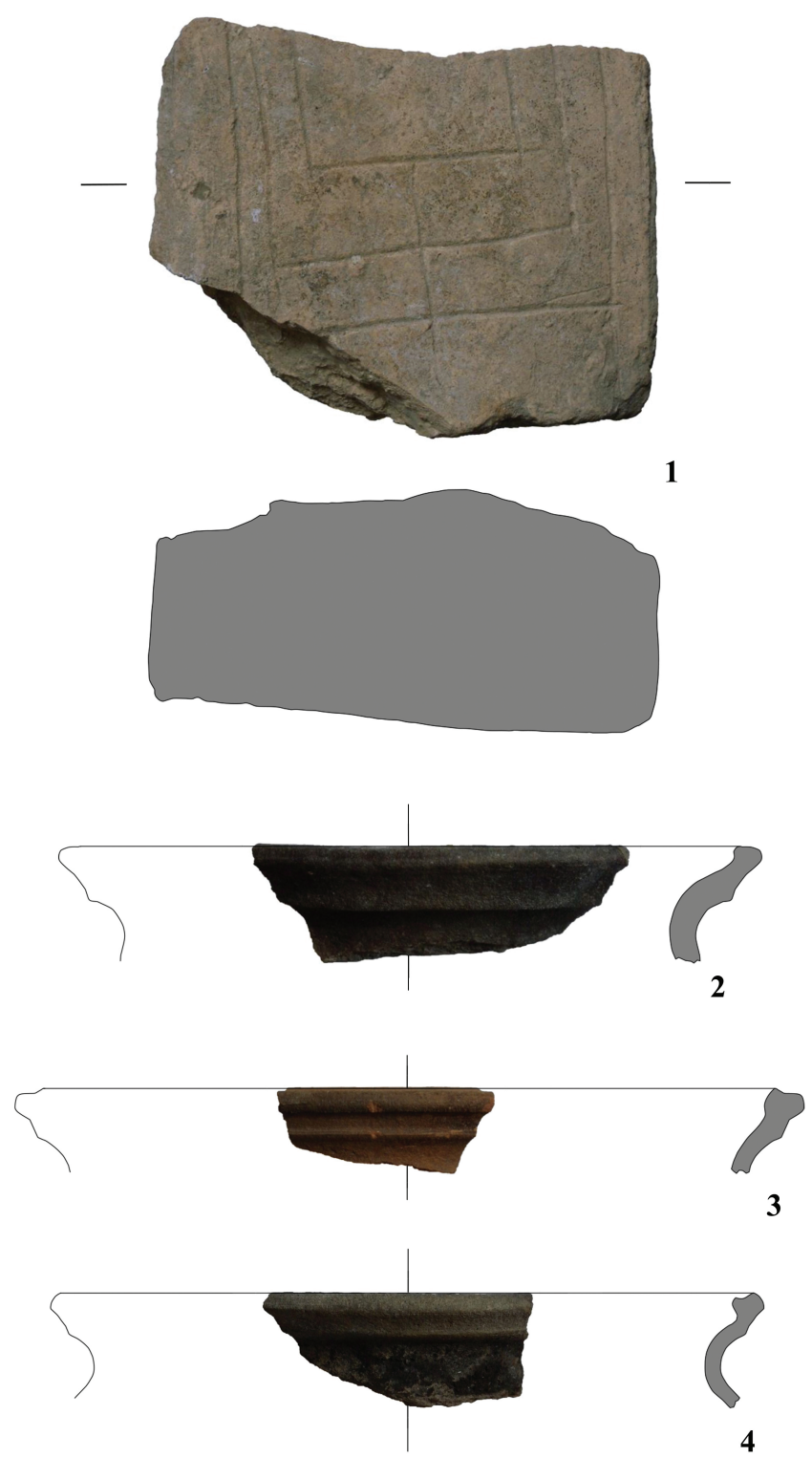

0

PI. IV Novi Sad, Klisa, finds from Feature 32 (drawing: V. Mogin; photo: D. Anđelić) T. IV Нови Сад, Клиса, налази из Објекта 32 (цртеж: В. Могин; фото: Д. Анђелић) 

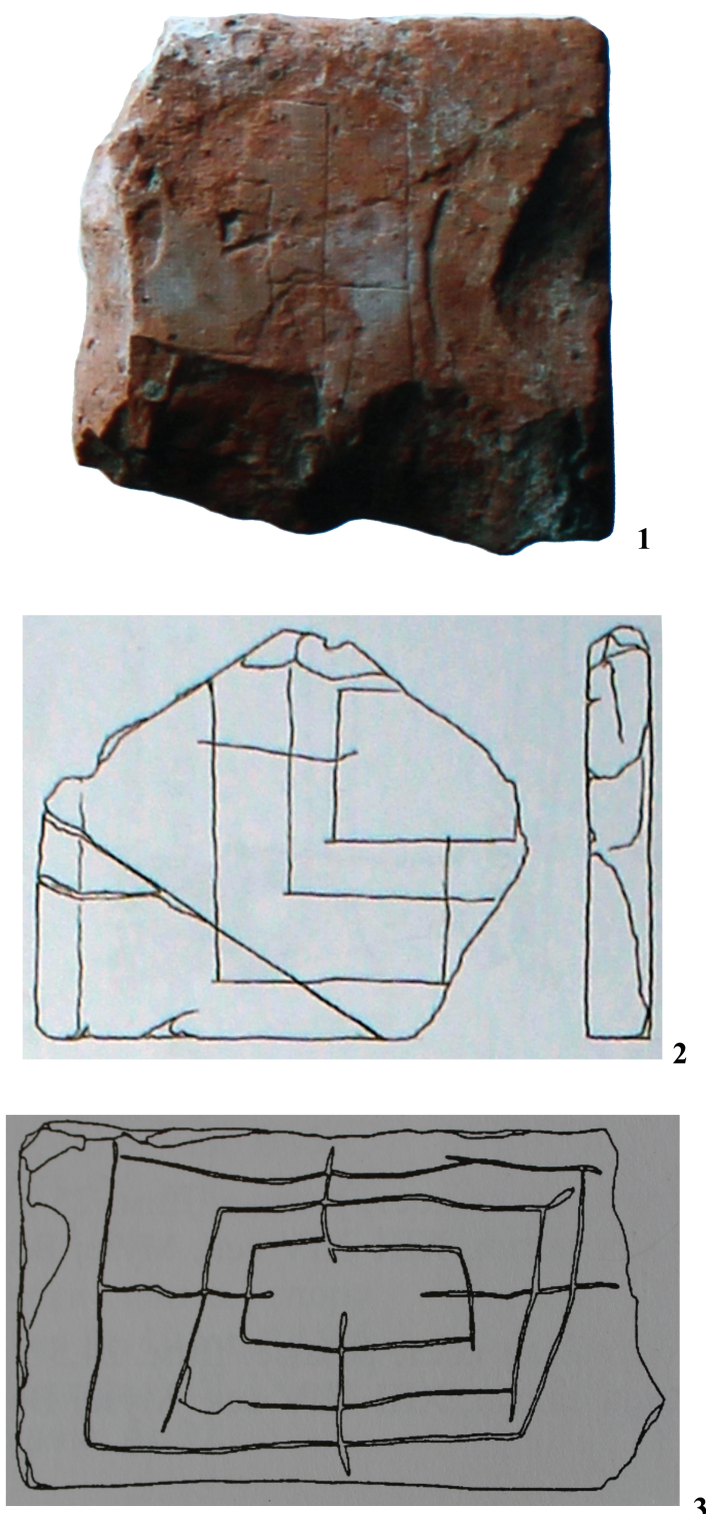

0.10. 5

PI. V 1. Bač, gaming board from the vicinity of the Franciscan monastery (source: Станојев 2019, 19, бр. 4); 2. Bač, gaming board from the traphole (source: Станојев 2019, 231, бр. 29); 3. Vrbas, gaming board (source: Вукотић и Станојев 1998, 28)

T. V 1. Бач, табла за игру из околине фрањевачког самостана (извор: Станојев 2019, 19, бр. 4); 2. Бач, табла за игру из вучје јаме (извор: Станојев 2019, 231, бр. 29); 3. Врбас, табла за игру (извор: Вукотић и Станојев 1998, 28) 